\title{
短周期微動への空間自己相関法 APPLICATION OF THE SPACE の適用における交通量の影響 \\ AUTOCORRELATION METHOD TO THE SHORT-PERIOD MICROTREMORS : INFLUENCES OF HEAVY TRAFFIC
}

\section{長 郁夫 一 $* 1$ 志賀卓弥 $-* 2$ 策崎祐三— $* 3$ \\ キーワード： \\ 微動，位相速度，空間自己相関法，探查法，速度構造}

Keywords

Microtremors, Phase velocity, Space autocorrelation method, Exploration method, Velocity Structure

\section{Ikuo CHO $-* 1 \quad$ Takuya SHIGA $-* 2$ \\ Yuzo SHINOZAKI —*3}

We have examined the effects of heavy traffic on dispersion curves analyzed by the space autocorrelation method. In order to observe short-period microtremors circular arrays of six seismometers with radiuses of 5 and $20 \mathrm{~m}$ were deployed at the position $200 \mathrm{~m}$ away from a road on which traffic was heavy. We took out waveforms with durations of 10 s from the array data, and estimated power spectral densities and spatial autocorrelation coefficients. Changing the start time of the waveform segments, we repeated this procedure over entire records. It is revealed that the phase velocities analyzed depend on the intensity of microtremors.

\section{1.はじめに}

1990 年代には, 短周期微動のアレイ観測に基づく浅い地下構造 推定の可能性が確認されてきた. 周波数一波数法 (FK), 空間自己 相関法 (SPAC) のいずれも分散曲線の解析に適用可能である. ${ }^{1), 2)}$ $\mathrm{SPAC}$ はK と比較してアレイ半径に対する解析可能波長帯域が 広くアレイを構成するセンサー数も少なくてすむから，観測効率に おいては SPACが有効である。

微動を用いた探査法の特色として，市街地における探査可能性が あげられる。しかし市街地では，観測点近くに道路があり時間帯に よらず車両等の発生する振動を避け難い場合も多い.

観測点に近い特定の振動源からの影響を強く受ける場合には，短 周期微動の一点観測による地盤特性の推定には問題がある. ${ }^{3)}$ しか しアレイ観測による分散曲線の解析に対して本質的な影響を及ぼす かは明らかではない

本研究の目的は, SPACを用いた分散曲線の解析に交通量の相違 が与える影響を吟味することである。この目的のために, 交通量の 多い道路近くを観測点として短周期微動のアレイ観測を試み, 得た データに SPAC を適用したので, 以下に報告する。

\section{2. 観測}

2000 年 10 月 18-19 日に東京理科大学野田キャンパス (千葉県野 田市山崎) で微動上下動のアレイ観測を実施した (図 1). 交通量の 多い道路 (国道 16 号線) から約 $200 \mathrm{~m}$ 南南西に離れた地点に, 同一 の特性を有する 6 台のセンサーで構成される円形アレイを展開し
た. 問題の道路は片側 2 車線の幹線道路で, 時間帯に依らず混み合 うものの通常は車両の流れに滞りはない. 観測時もそれに変わりは なく, 観測点近くの信号機の変化によりほほ一定の時間間隔で交通 の流れが寸断されるという状況だった。

短周期微動の解析を前提としてアレイ半径を $20 \mathrm{~m}, 5 \mathrm{~m}$ とした. アレイを展開したのは見通しの良い芝生のグランドの中央で, 周囲 に建造物はなく直下にも人工的な地下構造物はない. 問題の道路上 の 1 点から見たアレイの広がりは, 半径 $20 \mathrm{~m}, 5 \mathrm{~m}$ の場合それぞれ 最大で $11^{\circ}, 3^{\circ}$ となる。道路上で励起されたアレイへの入射波は， 平面波で近似可能と考えられる。

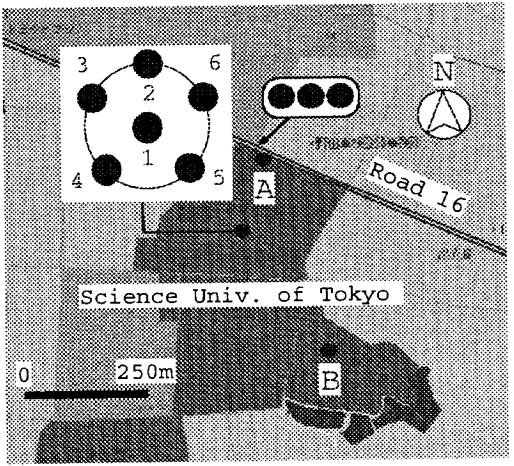

図 1 観測点

センサーには, (株) 東京測振製のサーボ型速度計 VSE-15D 型を 用いた.レコーダーには同社製の SPC-51 型を用い, 16 ビットで $\mathrm{AD}$ 変換して $100 \mathrm{~Hz}$ でサンプリングした. センサーとレコーダーを

\footnotetext{
*1 Research Assoc., Dept. of Architecture, Science University of Tokyo, Dr. Sci.

*2 Graduate Student, Dept. of Architecture, Science University of Tokyo

*3 Prof., Dept. of Architecture, Science Univ. of Tokyo, Dr. Eng.
} 
含めた総合的な周波数特性は, 今回の解析で使用可能性のある $1 \mathrm{~Hz}$ から $20 \mathrm{~Hz}$ 程度の周波数帯域で, 振幅特性, 位相特性ともに平坦で ある. 測定感度は 16 ビットフルスケールで $1 \mathrm{~cm} / \mathrm{s}$ とした.

半径 $5 \mathrm{~m}, 20 \mathrm{~m}$ のアレイ観測をそれぞれ深夜, 早朝に行った. 観 測時はほほ無風状態で, アレイ近傍およびアレイ内部に微動の振動 源は認められなかった．記録時間はいずれも約 13 分間程度である.

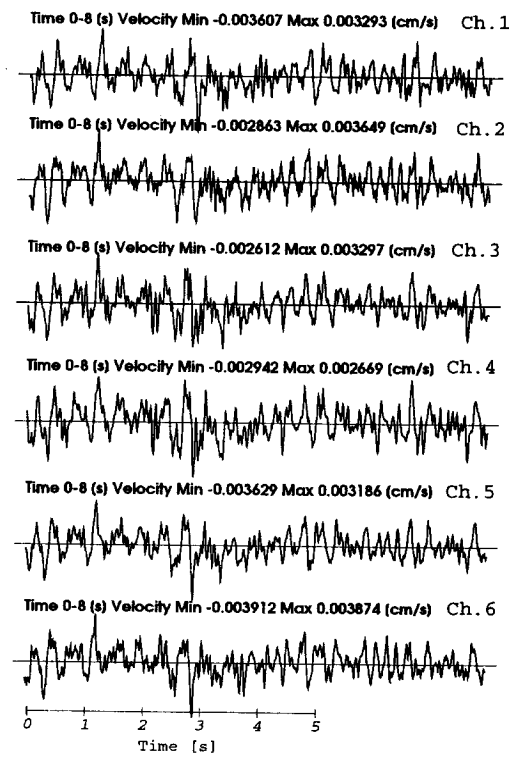

図 2 各チャンネルの微動波形の比較

図 2 に $5 \mathrm{~m}$ のアレイで得た波形記録 (8 秒間) を例として示す.こ の例に示されるように, 得た微動波形において $3 \mathrm{~Hz}$ 程度の成分は常 に卓越するようである. $10 \mathrm{~Hz}$ 以上の高周波数成分も含まれる。 セ ンサーごとの微動波形を比較すると，位相の対応がつくものが多い ことが分かる。

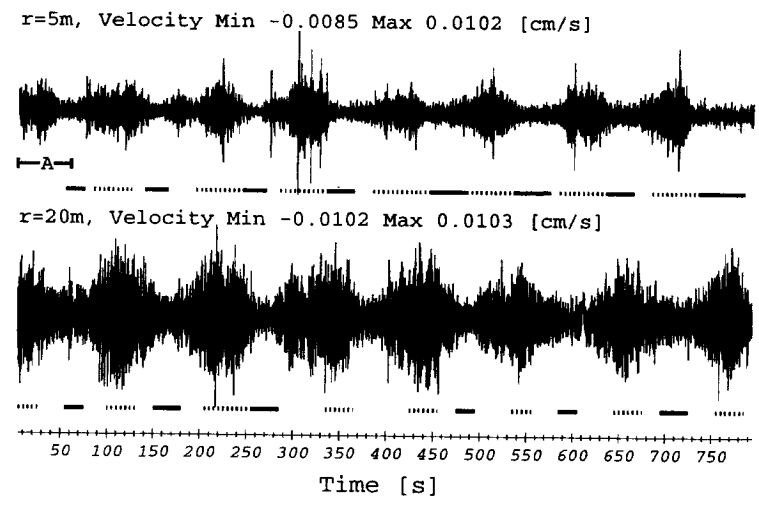

図 3 中心観測点における微動波形

記録時間を通しての微動波形の概観は，図 3 に示すように, 80-120 秒程度の時間間隔で包絡線振幅が繰り返し変化する様相を呈するこ とが分かった．この繰り返しの時間間隔は, 道路沿いの信号機が変 化する時間間隔と密接に関係する。

図 4 は, 2000 年 10 月 27 日の日中同観測点において微動の 1 点 観測を行い, 同時に観測点に近接する信号機の近く(図 1のA 地 点) で交通量調查を実施した結果である，包絡線振幅の変化が，信 号機の変化に促される通過車両数の変化に対応していることが分か る.な扮同図において信号機が青以外の時間帯で通過車両数が零で
ない場合があるのは, 交差点からの少量の左折車が通過するためで ある. 図 3 の観測波形に見られる包絡線振幅の時間変化も，近くの 道路 (国道 16 号線) の交通量に関係すると考えられる。

アレイ観測後に, 6 台の地震計を一䈉所に設置して観測精度を榆 定した．実施地点は，観測点から約 $300 \mathrm{~m}$ 南南東の待機地点 (図 1 の $\mathrm{B}$ 地点) である. 図 5 は，得られた波形，パワースペクトルおよ びコヒーレンスの例である. スペクトルの計算には, 次節の解析と 同様のパラメータを用いた。交通量の多い道路からは約 $500 \mathrm{~m}$ 離れ ているためアレイ観測時ほど目立たないが, 微動波形の包絡線振幅 はアレイ観測時と同様の時間変化を呈する.

図 5 によれば, $3 \mathrm{~Hz}$ 程度の周波数帯域は包絡線振幅によらず卓越 する. 包絡線振幅の大きい時間帯には $3,5,10 \mathrm{~Hz}$ 程度の周波数帯 域で微動の強度 (パワー) が 10 から $20 \mathrm{~dB}$ 程強くなる. 6 台のセン サーに対応するパワースペクトルは $1-10 \mathrm{~Hz}$ で互いに良く一致する. コヒーレンスは包絡線の振幅によらず $2-5 \mathrm{~Hz}$ の周波数帯域ではほ ぼ 1 となる. 低周波数側と高周波数側で微動の強度が弱くなると, コヒーレンスも低下する. 高周波数側におけるコヒーレンスの低下 は $8-10 \mathrm{~Hz}$ まで数\%以内だが, $10 \mathrm{~Hz}$ を越えると急激に低下する。

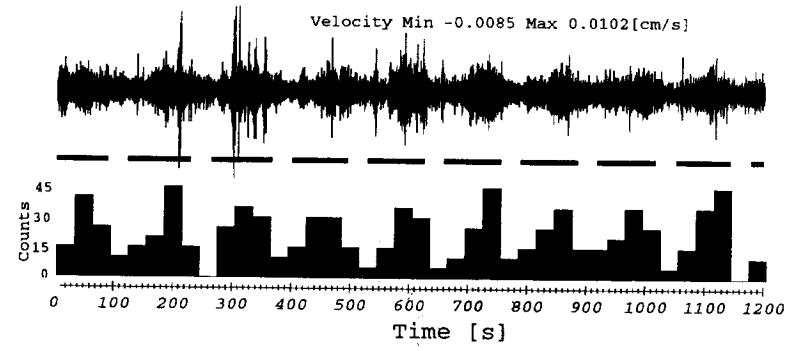

図 4 微動波形 (上), 信号機が青の時間 (中), および通過車雨数 (下)

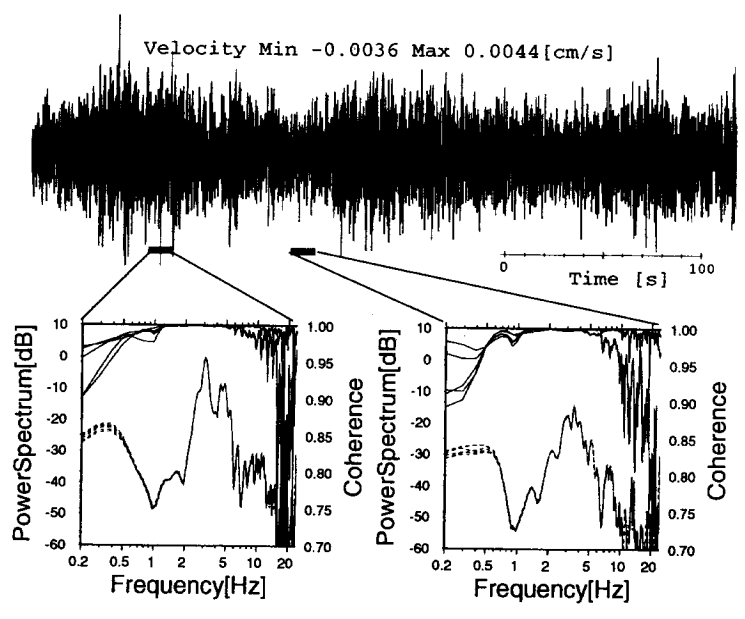

図 5 パワースペクトル (点線) とコヒーレンス (実線)

\section{3. パワースペクトルと空間自己相関係数}

アレイ観測で得た微動データの統計的な特徴を把握するために， パワースペクトルを推定する. 図 3 の微動波形上で短いデー夕区間 を取り，データ区間内は定常確率過程とみなせるとして, デー夕区 間の開始時刻をずらしながら次々にそれぞれの部分についてパワー スペクトルを推定する (以降, 短時間パワースペクトルと呼ぶ).

データ区間長が短かすぎると統計的な特徴の把握が難しくなり， 
長すぎると定常性の近似が破綻をきたす．SPACの適用のために は，両方の条件が必要である. 図 6 に，半径 $5 \mathrm{~m}$ のアレイ観測で得 た微動波形 (図 3 の A 部) を 10 秒ずつ区切って示す. 図 3 の A 部 には包絡線振幅の大きい時間帯と小さい時間带, 過渡的な時間帯の いずれも含まれる。しかし 10 秒程度で区切れば各デー夕区間内に おける包絡線振幅の変化はかなり緩やかになり，微動波形全体の場 合 (図 3) と比較して変化が目立たなくなる。データ区間長を 5-10 秒程度とすれば, 数 $\mathrm{Hz}$ 程度の周波数帯域が解析可能で, デー夕区間 内に掠ける定常性の仮定も近似的に満足できると考えられる。他の データ区間および半径 $20 \mathrm{~m}$ の場合についても同様の結論を得た.
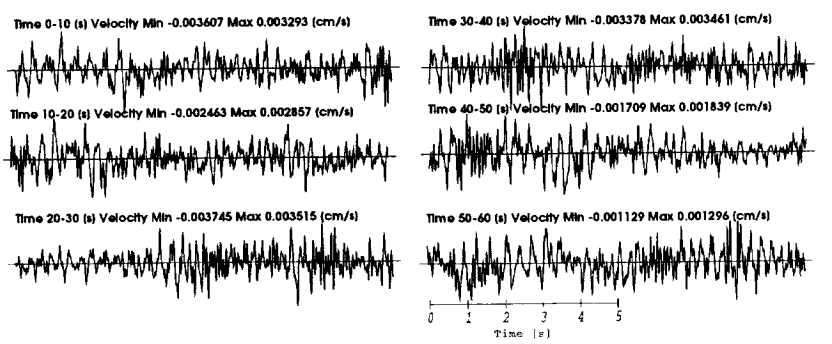

図 6 各データ区間 (10 秒間)における微動波形の比較

データ区間長を約 10 秒間として, 各データ区間について FFTに よる直接法でパワースペクトルを推定する．5.12 秒間の微動波形 を 2.5 秒ずつ 3 回ずらし，それぞれにテーパー率 0.5 のハニングウ インドウをかけて FFT を施す. 得られたそれぞれのフーリエスペ クトルにその複素共役をかけてアンサンブル平均をとる.バンド幅 $0.3 \mathrm{~Hz}$ のパルゼンウインドウをかけて最後に振幅の補正を施す. 5 秒刻みにデー夕区間の開始時刻をずらしながらこの作業を繰り返す。

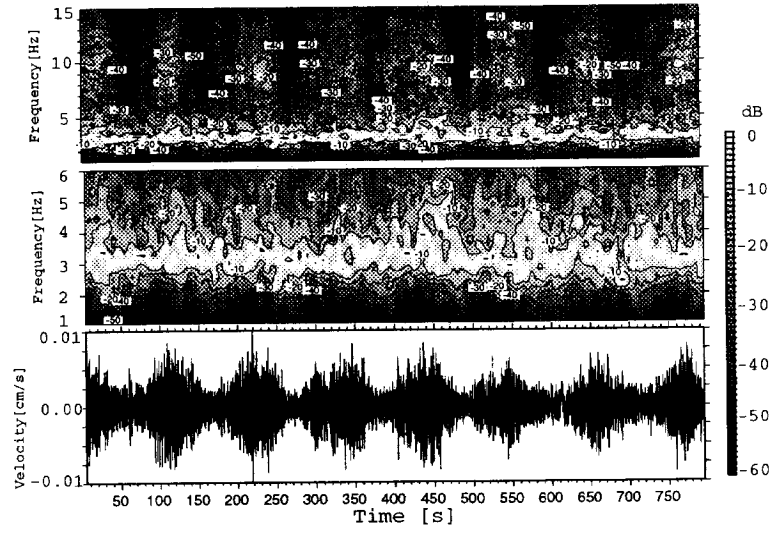

図 7 半径 $20 \mathrm{~m}$ のアレイの中心観測点の微動波形 (下) および短 時間パワースペクトル (上) とその拡大図 (中)

図 7 は, 短時間パワースペクトルと波形の比較である. 半径 $20 \mathrm{~m}$ のアレイの中心観測点の場合を示した. 周波数成分間の相対的な強 度に関寸る時間変化を調べるために, 各デー夕区間のパワースペク トルはそれぞれ最大值で正規化してある．時間領域および周波数領 域のウインドウ操作とアンサンブル平均による平滑化の作用で, 各 データ区間においてパワースペクトルは比較的安定に得られている。

図 7 より, $3 \mathrm{~Hz}$ 程度は包絡線振幅の変化によらず常に卓越するこ とが分かる. 2.8-3.6Hzの周波数帯域は, 包絡線振幅の相違にかか わらず- $10 \mathrm{~dB}$ 以上の強度を維持する. $6 \mathrm{~Hz}$ 以上の周波数帯域は, 包 絡線振幅が小さいデー夕区間ではあまり励起されない。
交通量の変化が SPACの適用に及ぼす本質的な影響を吟味する ためには，空間自己相関係数 $\rho(f)$ をデータ区間ごと推定し，対応 するデー夕区間の波形あるいはパワースペクトルと比較するのが効 果的である. 空間自己相関係数は, 中心観測点と円周上の観測点間 のクロススペクトルの方位平均を中心観測点のパワースペクトルで 正規化して得られるが, 中心観測点と円周上の観測点間のコヒーレ ンスの方位平均で置き換えることによりゲインのばらつきを補正可 能である. ${ }^{2)}$ 本研究では後者を採用する.SPACによれば空間自己 相関係数はべッセル関数となる，その逆関数を計算すれば位相速度 が得られるが, その際低周波数側と高周波数側で誤差が拡大される. したがって微動波形あるいはパワースペクトルを分散曲線と直接比 較しても，交通量の変化が及ぼす本質的な影響を把握しにくい.

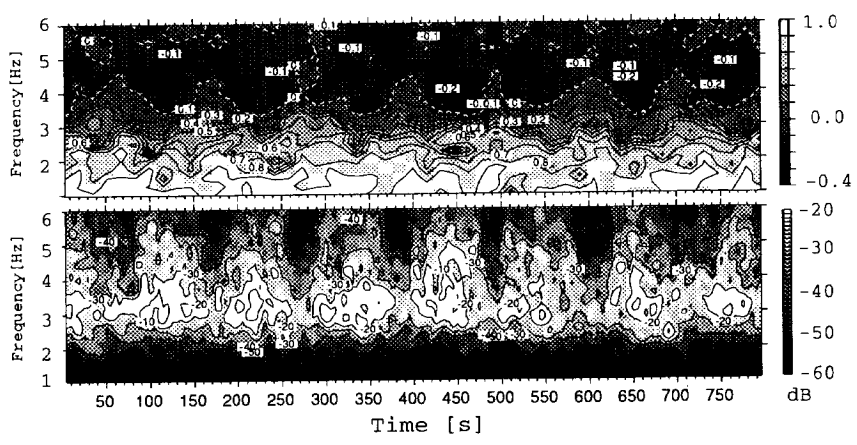

図 8 半径 $20 \mathrm{~m}$ のアレイの中心観測点における短時間パワースペ クトル (下) と空間自己相関係数の時間変化 (上)

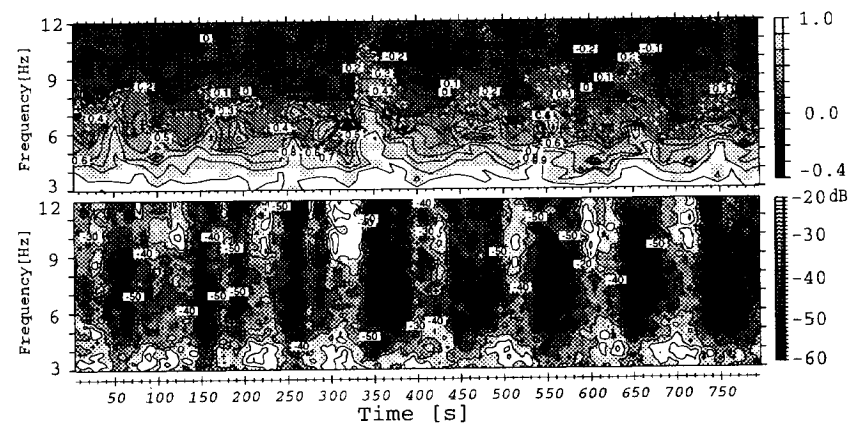

図 9 半径 $5 \mathrm{~m}$ のアレイの中心観測点における短時間パワースペク トル (下) と空間自己相関係数の時間変化 (上)

図 8 に, 空間自己相関係数の時間変化を短時間パワースペクトル と比較する。本研究では, 波形に現れる交通の影響をパワースペク トルにより取り扱う，同図において，各データ区間のパワースペク トルは全データ区間の最大值で正規化した．短時間パワースペクト ルがデー夕区間長 (約 10 秒間) に比べて比較的緩やかに変化する事 実は，データ区間内に扔ける定常性の仮定の妥当性を支持する，パ ワースペクトルに混入する小さな振動が空間自己相関係数にも混入 してはいるが, 概観をとらえるには問題のない程度である。

図 8 によれば, 空間自己相関係数はパワースペクトルの時間変化 に対応して変化することが分かる，微動の強度が強いデー夕区間で は空間自己相関係数の傾斜が急で, 弱いデー夕区間では緩やかであ る.デー夕区間によらず相対的な強度を維持する $3 \mathrm{~Hz}$ 程度の周波 数帯域 (図 7 中) も例外ではない.

空間自己相関係数の時間変化は, 強度の低下による観測精度の悪 
化に起因するわけではない. 観測精度の検定時の微動波形の包絡線 振幅はアレイ観測時より常に小さいが, $3 \mathrm{~Hz}$ 程度の周波数帯域のコ ヒーレンスはほほ 1 となった。

半径 $5 \mathrm{~m}$ の場合も短時間パワースペクトルと空間自己相関係数の 時間変化には半径 $20 \mathrm{~m}$ の場合と同様の対応関係が見られる (図 9).
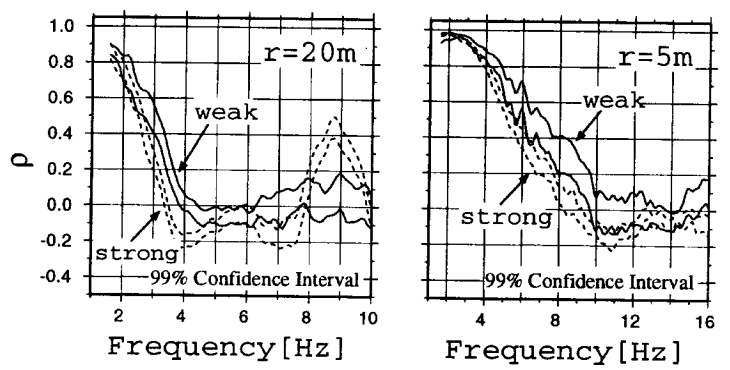

図 10 微動の強度の相違が空間自己相関係数に与える影響

図 10 に, 微動の強度が強いデー夕区間と弱いデー夕区間 (それぞ れ図 3 の横点線と横実線) で得た空間自己相関係数の平均を $99 \%$ 信 頼区間で示す.デー夕区間の選定には，強度の相違を特徽的に示す $10 \mathrm{~Hz}$ 程度の周波数成分の強度を特に参考とした。図 10 は，微動 の強度が空間自己相関係数に影響を与えることを支持する. $3 \mathrm{~Hz}$ 程 度に着目すると, 半径 $5 \mathrm{~m}$ の場合空間自己相関係数はほほ 1 となる ため相違が見えにくいが，半径 $20 \mathrm{~m}$ の場合は空間自己相関係数は 有意に異なる.アレイ半径, 微動の強度, および観測精度から, 半径 $20 \mathrm{~m}, 3 \mathrm{~Hz}$ 程度の周波数帯域の解析結果には信頼性がある.

\section{4. 分散曲線}

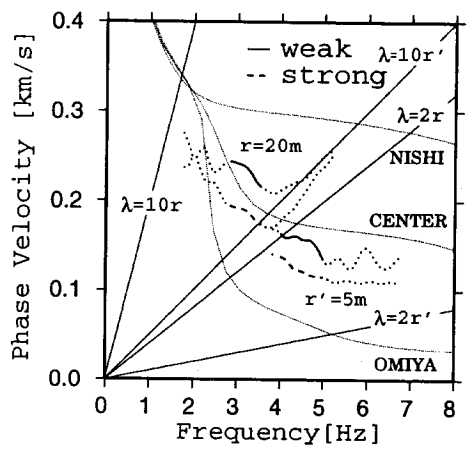

図 11 微動の強度の相違が位相速度に与える影響

図 11 は，前節で得た空間自己相関係数の平均値から計算した位相 速度である．同図には参考として，関東平野で良く見られる典型的 な 3 種類の速度構造 ${ }^{2}$ (NISHI, CENTER, OMIYA) から計算し たレイリー波の基本モードの位相速度も示す. NISHI は関東ローム と砂礫層の洪積台地, CENTER は沖積層の氾濫原性低地, OMIYA は軟弱な腐食土が厚い谷底低地の土質に対応する.SPACによる解 析が可能な波長带域の目安はアレイ半径 $r$ の 2-10 倍程度だから, ${ }^{4)}$ 同図には, 波長 $\lambda=2 r, 10 r$ の直線も示した. 解析結果が意味を持つ のは,これらの直線に挟まれる領域ということになる。これらの比 較により，解析された分散曲線がレイリー波の基本モードとして自 然な範囲に推定されていることが分かる.

図 11 が提起する問題点は, 微動の強度が強いデー夕区間から得 た位相速度が，強度が弱いデータ区間から得た位相速度よりも20-
$50 \mathrm{~m} / \mathrm{s}$ 程度系統的に低く評価される事実である。また図 11 の解析 結果はいずれも CENTERに近い.しかし観測点付近の土質構成は むしろ NISHI に近いと考えられるのである。アレイ直下の速度構 造については既存のデータがないので検層等による今後のデータ取 得に負うことになるが, 観測点から約 $400 \mathrm{~m}$ 南南西の地点で明らか にされている土質構造 (<約 $40 \mathrm{~m}$ 深) は, 表層から関東口ーム層， 常総粘土層, 成田層群という洪積世の層序となることが分かってい る (図 12).この層序は, 観測点の位置する下総台地の北西部におい てごく一般的に見られる土質構成である.

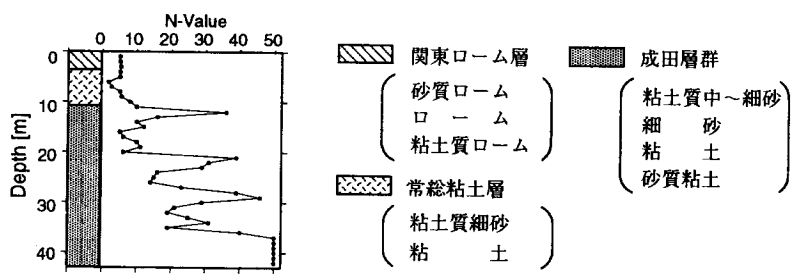

図 12 観測点付近の土質構造

\section{5. 考察とまとめ}

本研究で明らかにされた観測事実は次の通りである。すなわち， 交通量の多い道路近くのデー夕にSPACを適用して推定された位 相速度は過小評価されている可能性が高く, 交通の流れが激しく微 動の強度が強くなれば過小評価の度合も強くなる. 過小評価は周波 数にも依存すると考えられるが詳細は不明である. 図 11 において 半径 $20 \mathrm{~m}$ と $5 \mathrm{~m}$ の分散曲線を安直につなぐべきではないだろう.

実体波の卓越が過小評価の原因となるとは考えにくい. 定量的な 評価は難しいが, 観測点近くの地表が振動源であるため表面波の卓 越が予想されるからである. 短時間のデー夕区間内における近似的 な定常性の破綻あるいは地盤の非線形性の効果等種々の原因が考え られるが，原因が特定できない以上は，一般には過小評価だけでな く過大評価もあり得ると考えておくべきだろう。

微動の強度が SPACによる位相速度の評価に系統的な影響を与 える原因の解明と一般性の吟味のためには, 交通状態のモニタリン グを併用した多くの観測が望まれる. 観測例の蓄積により，位相速 度の系統的なバイアスに対する経験的な補正も可能となるかもしれ ない. 市街地における短周期微動を用いた地下構造の探査に対する SPAC の適用性を高めることができると期待している.

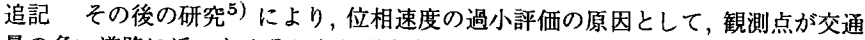
量の多い道路に近いためそこから到来する強い方向性を持つ微動とその反射波等 が他の振動源から到来する微動よりも卓越して干涉した可能性が示された.

謝辞観測に際して, (財) 地域地盤環境研究所から GPS 時刻コード出力装置 を掞借りした．同研究所の宮腰研博士との議論は交通の影響を判断する上でたい へん参考となった．東京理科大学の井口道雄教授から観測点付近の地質について 御教授頂いた. 本研究の一部は平成 12 年度文部省科学研究費補助金, 基盤研究 (B) (No.11450207, 研究代表者 篠崎祐三)により遂行された.

参考文献

1）山本英和ほか 5 名: 短周期微動のアレイ観測による盛岡市域の地下速度構造, 物理探査, Vol.50, No.2, pp.93-106, 1997

2）松岡達郎, 梅沢夏実, 巻島秀男: 地下構造推定のための空間自己相関法の適用 性に関する検討, 物理探査, Vol.49, No.1, pp.26-41，1996

3) 鏡味洋史: 微動観測とその工学的利用, 地学雑誌, Vol.97, No.5, pp.409-422, 1988

4) 物探探査学会: 物理探査ハンドブック,pp.203-211, 1998.3

5）長郁夫, 志賀卓弥, 篠崎祐三: 短周期微動の場における相関構造の形成: 分散 曲線の解析における交通量の影響, 2001 年度日本建築学会大会 (関東) 学術 講演梗概集 (構造系) に揭載予定.

[2001年 4 月20日原稿受理 2001年 7 月27日採用決定］ 